\title{
As muitas faces do compadrio de escravos: o caso da Freguesia de São José dos Pinhais (PR), na passagem do século XVIII para o XIX'
}

Cacilda Machado

UFRJ

ResUMo

O cruzamento de registros paroquiais (batismo, casamento e óbito) com censos domiciliares e com a genealogia de uma família senhorial permite aprofundar discussões tradicionais na historiografia, acerca das alianças de parentesco ritual efetuadas por escravos. Este artigo sugere que as relações de compadrio dos cativos de São José dos Pinhais (PR) eram mecanismo de manutenção e de ampliação de uma comunidade de negros e pardos, e mesmo de brancos pobres. No entanto, o predomínio de pequenos proprietários de escravos tornou o compadrio estratégico também na busca de proteção social, por parte dos escravos, e instrumento de controle senhorial. Tais características acabaram por reforçar o componente de dominação/submissão e ajudaram a debilitar o caráter igualitário que o parentesco espiritual tridentino também pressupunha, contribuindo para a reprodução da hierarquia social.

Palavras-chave: Escravidão; Compadrio; Hieraquia social.

\section{ABSTRACT}

Through crossing parochial records (baptisms, marriages and deaths) with census data (Listas Nominativas de $\mathrm{Ha}$ bitantes) and a genealogy of a master family, this article aim to deepen traditional historiographical discussions about slave's ritual kinship alliances. The article suggest that slave's compadrio relations in São José dos Pinhais (PR) was a mechanism of maintenance and enlargement of a community of negroes, pardos and white poors. However, in this area where predominated owners with few slaves, compadrio was useful to social protection and also an instrument of master control. These characteristics reinforced the mark of dominationsubmission, and helped to debilitate the equalitarian character also presupposed by Catholic ritual kinship, thus contributing to reproduction of social hierarchy.

Keywords: Slavery; Compadrio; Social hierarchy. 
Dentre os estudos sobre escravidão, há algum tempo vêm se destacando aqueles que dedicam especial atenção às relações de compadrio. Talvez porque o batismo foi o sacramento católico mais comum entre os escravos, que através dele multiplicaram os laços de parentesco espiritual, dentro e fora do cativeiro.

A partir dos resultados das pesquisas empreendidas, alguns tópicos de discussão se destacam, entre os quais a compreensão do compadrio no âmbito da relação senhor-escravo. Em um estudo pioneiro no Brasil, Gudeman e Schwartz indicaram que, no Recôncavo baiano, na década de 1780, foi extremamente raro o apadrinhamento de cativos por seus senhores. ${ }^{2}$ Para os autores, havia incompatibilidade entre propriedade escrava e parentesco espiritual, e a saída para essa incompatibilidade não consistiu em abolir o batismo ou a escravidão, mas mantê-los separados. Dessa forma, tais autores põem em dúvida a existência de relações paternalistas entre senhores e seus cativos.

Trabalhos posteriores vêm confirmando tais inferências, pois, em geral, os pesquisadores encontraram pouquíssimos casos de compadrio de escravos com seus senhores. ${ }^{3}$ Quase todos concordam, igualmente, que a despeito disso a instituição não deixava de se constituir em uma aliança hierárquica, já que muito raramente um escravo era padrinho ou madrinha de uma criança livre, e os cativos tendiam a preferir madrinhas e, especialmente, padrinhos forros ou livres para seus filhos, sobretudo os cativos de unidades escravistas de pequeno porte. Robert Slenes, por exemplo, escreveu que a construção, pelos escravos, de relações de compadrio que ultrapassavam os limites do cativeiro demonstra "a necessidade, num mundo hostil, de criar laços morais com pessoas de recursos, para proteger-se a si e aos filhos". ${ }^{4}$ De fato, muitos autores já nos forneceram notáveis testemunhos de como os laços de compadrio com pessoa de maior importância podiam beneficiar compadre/comadre ou afilhado, sobretudo mediante heranças. Silvia Brügger, além disso, demonstrou a complexidade do compadrio, indicando a existência de laços de solidariedade entre padrinhos e afilhados e entre compadres, mas também revelando o componente de dominação presente nessas relações. ${ }^{5}$

De fato, o compadrio comportava inúmeros conteúdos políticos. Nas regiões com predomínio de grandes escravarias, por exemplo, o percentual de escravos apadrinhando escravos era bem mais significativo. ${ }^{6}$ Para José Roberto Góes, nesses casos o compadrio era uma das formas de incorporar os africanos recém-chegados, e de propiciar meios de socialização de modo a formar uma comunidade escrava. ${ }^{7}$ No entanto, alguns autores ressaltam que o caráter hierárquico não estava necessariamente ausente no compadrio entre 
cativos, pois em geral os escravos domésticos ou os que possuíam algum tipo de qualificação profissional apadrinhavam mais do que os escravos de roça. ${ }^{8}$

Neste artigo, procuro discutir tais questões a partir da análise das relações de compadrio estabelecidas por escravos de São José dos Pinhais, na passagem do século XVIII para o XIX. No período, esse vilarejo era freguesia da vila de Curitiba, situada a sudeste desta, em direção à Serra do Mar. Seus habitantes viviam basicamente da pecuária e da agricultura de subsistência e abastecimento do mercado interno, e uma característica dessa população era a forte presença de pardos entre os livres, oscilando, no período, em torno de 40 por cento. ${ }^{9}$

Em 1782, a população de São José compunha-se de aproximadamente mil pessoas, sendo escravas 15 por cento delas. ${ }^{10}$ Em 1804, 11,5 por cento dos 1.894 habitantes eram escravos; em 1830, estavam nessa condição apenas 10,2 por cento dos 3.240 habitantes. ${ }^{11}$ Em todo o período, esses cativos pertenciam a poucos senhores: em 1782 e em 1803, não havia escravos em 80,5 por cento dos domicílios da freguesia. Esse índice subiu para 83,7 por cento, em 1827. Além disso, a maior parte dos escravistas do lugar tinha no máximo quatro cativos, tendência que se acentuou ao longo do tempo: em 1782, 58 por cento dos escravistas da freguesia possuíam de um a quatro cativos; em 1803 esse índice era de 66 por cento, e de 75 por cento, em $1827 .{ }^{12}$

Em todo o período o grupo cativo de São José dos Pinhais apresentava um perfil sexo-etário muito semelhante ao dos livres, compondo-se ambos de muitas crianças e com equilíbrio dos sexos. Isso significa que, por então, compravam-se poucos escravos no mercado externo à freguesia. Para a reposição ou incremento de suas escravarias, portanto, aqueles pequenos senhores dependiam basicamente da reprodução endógena da comunidade de cativos.

Esse quadro talvez possa ser estendido a boa parte da Capitania de São Paulo, pois os autores que estudam a escravidão paulista nas áreas econômicas de subsistência e abastecimento costumam encontrar uma estrutura sexo-etária bastante semelhante à de São José dos Pinhais. Francisco Vidal Luna, por exemplo, ao estudar treze localidades da Capitania de São Paulo, em 1776, 1804 e 1829, a partir de listas nominativas, observou que, nas áreas de exportação, a razão de masculinidade era mais alta do que nas de subsistência e abastecimento, nas quais existia maior equilíbrio quantitativo entre os sexos. As áreas de cultivo para exportação apresentaram os menores índices de população cativa infantil. Inversamente, em Curitiba, Mogi das Cruzes, São Paulo e São Sebastião resultaram os maiores valores, a refletir, para o autor, a predominância de atividades pouco voltadas para o mercado externo e, 
portanto, com menor capacidade de compra de novos escravos adultos, em idade produtiva, servindo-se, provavelmente, de uma maior parcela de cativos nascidos na própria região. ${ }^{13}$

Um estudo sobre compadrio de escravos tem especial interesse para o presente trabalho, pois resultou de uma ampla pesquisa nos registros de batismo da paróquia de Nossa Senhora da Luz dos Pinhais (em Curitiba), nos séculos XVIII e XIX, coordenada por Stuart Schwartz. No artigo em que relata os resultados do trabalho, o autor destaca que, tal como em sua pesquisa anterior, o já citado estudo com Gudeman, na Bahia, também em Curitiba o padrão era o apadrinhamento de crianças escravas preferencialmente por pessoas livres ou libertas.

Esse padrão aparece desde fins do século XVII, alterando-se entre 1750 e 1799, quando a proporção de padrinhos livres caiu para menos da metade, talvez em razão do grande número de adultos que chegaram nesses anos os escravos adultos do Brasil raramente tinham padrinhos livres. Depois de 1800 ressurgiu o antigo padrão. Dos 504 batismos da paróquia curitibana entre 1800 e 1869, 70 por cento tiveram um par de padrinhos livres, menos de 20 por cento tiveram dois escravos como padrinhos, e quando os dois padrinhos tinham status desigual, o afilhado tinha duas vezes mais probabilidade de ter madrinha escrava e padrinho livre do que o contrário. Quando se escolhiam escravos para apadrinhar, na maioria dos casos não eram escravos do mesmo proprietário do batizado, talvez porque em geral as escravarias fossem pequenas em Curitiba, mas também sugerindo a capacidade de formar laços além dos limites da propriedade. Segundo Schwartz, o padrão da Bahia e do Paraná indica que talvez houvesse reconhecimento da importância social do padrinho livre, que poderia fazer as vezes de protetor e intercessor no futuro. Mas uma estratégia paralela e prática consistia em levar em conta a possibilidade de, em caso de morte da mãe, a madrinha escrava assumir a responsabilidade pela criação do afilhado. ${ }^{14}$

No texto Schwartz enfatiza uma especificidade da região: no Paraná, sob o regime da 'administração', a mão-de-obra indígena foi amplamente utilizada até meados do século XVIII. Embora esses administrados vivessem de fato como escravos, o autor observou que na comparação com os cativos havia diferenças importantes nos batismos de seus filhos: entre 1685 e 1750, somente 7 por cento dos escravos de Curitiba tiveram o senhor ou um parente deste como padrinho ou madrinha. No entanto, eles ou seus parentes batizaram 21 por cento dos filhos de seus administrados. No período entre 1750 e 1820 nenhum escravo negro foi batizado pelo próprio senhor, e em somente 5 por 
cento dos batismos o padrinho ou a madrinha era parente do proprietário do cativo.

De 1820 até a abolição da escravatura, em 1888, a separação entre o status de senhor e o de padrinho continuava sendo a norma predominante. Nesse período, dos 444 casos examinados, em somente três deles os senhores batizaram os próprios escravos. Também não se demonstrava paternalismo por meio do batismo por algum membro da família do senhor de escravos. De 1685 a 1850, somente 2,3 por cento (41/1.764) dos padrinhos eram parentes dos senhores dos escravos batizados. A partir desses resultados o autor sugere a existência de uma postura geral com relação aos índios bem diferente daquela expressa com relação aos negros.

Afinal, a justificativa de administrar índios eram os aspectos civilizadores de fazer com que tivessem contato com cristãos, que lhes ensinariam o comportamento apropriado de membros da igreja e da sociedade civil. Assim, se os senhores levavam a sério seu papel, não havia incongruência e, de fato, haveria motivos consideráveis para que fossem tanto senhores quanto padrinhos de batismos dos índios que estavam sob sua tutela ... Está bem claro que, com o deslocamento para a escravidão negra, surgira outro padrão de compadrio, semelhante ao observado na Bahia, no qual os papéis de senhor e padrinho eram considerados contraditórios. ${ }^{15}$

Uma vez que São José dos Pinhais era freguesia de Curitiba e apresentava características econômicas e demográficas semelhantes às daquela vila inclusive a forte presença de pequenas escravarias —, é praticamente certo que também ali os livres, predominantemente, apadrinhassem as crianças escravas. De fato, para a confecção do presente artigo manipulei um total de 114 registros de batismos, sendo 29 registros de filhos de negros ou pardos forros ou livres, e 85 registros de crianças que tinham ao menos um dos pais escravo. Desse último total, 67 eram crianças de mãe escrava (e pai livre, forro ou escravo), e 55 tiveram padrinhos e madrinhas livres (em apenas um deles a senhora era a madrinha). Em dois desses batismos o padrinho era livre e a madrinha escrava; um batismo teve padrinho escravo e madrinha forra; em nove batismos ambos os padrinhos eram escravos. Dos 18 batismos em que apenas o pai da criança era cativo, 17 tiveram padrinhos livres, e em um o padrinho era livre e a madrinha escrava. Finalmente, em todos aqueles 29 batismos em que ambos os pais eram forros ou livres de cor, os padrinhos eram forros ou livres. Por essas características, portanto, vale a pena analisá-los no 
contexto em que ocorreram e, dessa forma, tentar acrescentar novos aspectos ao quadro historiográfico já existente.

\section{Compadrio de Dorotéia e de Elena, ESCRAVAS DE ANTONIO dos Santos TeIXEIRA}

Entre 1784 e 1796 a escrava Dorotéia batizou cinco filhos na paróquia de São José dos Pinhais, e teve oito filhos batizados a cativa Elena. Embora pertencessem a um mesmo senhor (o Alferes Antonio dos Santos Teixeira) e tivessem, ambas, prole ilegítima, fizeram escolhas muito distintas no que diz respeito ao status dos padrinhos de seus filhos: eram todos brancos os compadres de Dorotéia, enquanto os filhos de Elena foram batizados por brancos, livres de cor e escravos.

Dorotéia, além disso, estabeleceu laços de compadrio com pessoas de maior distinção. Sua primeira filha, Felizarda, foi batizada em 1784, tendo como padrinhos José e Josefa, filhos de Ignácio José Preto. ${ }^{16}$ Esse último possivelmente era vizinho do Alferes Antonio dos Santos, pois no período os seus domicílios aparecem um após o outro ou próximos nas listas nominativas da freguesia. Além disso, Ignácio José Preto era sobrinho de Margarida Oliveira Leão (a esposa de Bernardo Martins Ferreira, escravista proprietário de Antonio e Simoa, cujo compadrio veremos adiante).$^{17}$

O segundo filho de Dorotéia foi apadrinhado por Manoel Vaz Torres e Angélica, filha de Antonio João de Oliveira (LBPSJP 1, 1787, 103v), ambos da elite escravista do lugar. Manoel Vaz Torres tinha um filho com o mesmo nome, de modo que não sei de qual se trata. Ambos, o pai e o filho, estavam registrados como proprietários de lojas e negociantes entre 1765 e 1784, e o primeiro fez o registro de dois escravos, como ferreiros, um em 1778 e outro em 1779. ${ }^{18} \mathrm{O}$ pai de Angélica, Antonio João de Oliveira, foi recenseado em 1790 com a mulher, os filhos e dois escravos. ${ }^{19}$

Dorotéia batizou outro menino em 1792, cujos padrinhos foram Francisco dos Santos e Francisca de Assis Pacheco, filhos solteiros de José dos Santos Pacheco (LBPSJP 1, 1792, 117), homem da elite da vila da Lapa, recenseado em 1798 como proprietário de 23 escravos. ${ }^{20}$ Aliás, outras escravas do alferes Antonio dos Santos Teixeira tinham ligações com pessoas daquela localidade. A cerimônia de batismo de uma filha dos cativos Felipe e Verônica, embora tenha ocorrido em São José dos Pinhais, foi oficiada pelo vigário da Lapa, e a criança teve como padrinhos dois moradores daquela vila (LBPSJP 1, 1776, 
87). Da mesma forma, Quitéria, filha de Anna, outra escrava de Antonio dos Santos, teve sua cerimônia de batismo realizada pelo vigário da Lapa, em São José dos Pinhais (LBPSJP 1, 1776, 86v). No entanto, não foi possível descobrir qual era essa ligação, mas pode ser que essas cativas ou suas famílias fossem naturais da Lapa.

Elias, também filho de Dorotéia, foi batizado em 1794 por Teodoro e Josefa, filhos solteiros do Sargento Comandante Tomás João Ferreira, e netos do já mencionado Bernardo Martins Ferreira (LBPSJP 1, 1794, 127). A última filha de Dorotéia foi apadrinhada por Francisco da Silva, casado, e Luiza Maria, viúva (LBPSJP 1, 1796, 132v). Sobre Luiza Maria não consegui obter qualquer informação, mas Francisco da Silva era casado com uma exposta (LCPSJP 1, 1784, 76) e não tinha escravos em 1793 (LNSJP 1793, dom. 25).

Eleutério, o primeiro filho de Elena, foi apadrinhado por Agostinho, escravo do vigário da freguesia, e por Verônica, escrava do mesmo alferes Antonio dos Santos Teixeira (LBPSJP 1, 1784, 96v/97). A escrava Verônica, agora com seu marido Felipe, também escravo do alferes, batizou uma outra filha de Elena em 1785 (LBPSJP 1, 101).

Os filhos de Elena nascidos após essa data tiveram todos padrinhos livres: Felisberta foi apadrinhada por Luis Antonio de Albuquerque, de Curitiba, e por Bárbara Cascais, filha de Maria Antonia Albuquerque, da freguesia (LBPSJP 1, 1787, 104v). Em razão do sobrenome eles provavelmente tinham parentesco entre si, e eram brancos, possivelmente. Além disso, Maria Antonia Albuquerque também tinha relações com pessoas da Lapa, pois em 1790, quando um sobrinho do Capitão João da Rocha Loures foi batizado em São José dos Pinhais, os padrinhos foram um casal da Lapa, por procuração apresentada por Maria Antonia.

A filha de Elena nascida em 1790 teve Salvador Siqueira e sua filha Maria do Rosário como padrinhos (LBPSJP 1, 106v), sendo o primeiro identificado como 'bastardo' na lista nominativa de 1790 (LNSJP, p.17). Maria, a filha batizada em 1792, foi apadrinhada por Francisco Oliveira Bueno, filho de Francisco Franco, e por Maria da Veiga, filha do falecido Antonio da Veiga Leme (LBPSJP 1, 119). O filho seguinte (LBPSJP 1, 1794, 124v) teve como padrinho José Leonel da Silva, também filho de Antonio da Veiga Leme. Em 1803 José Leonel foi recenseado como branco, fazendeiro e sem escravos (LNSJP, dom. 119). A madrinha foi Rita Cabral, filha de João Cabral, um músico, também branco (LNSJP, 1803, dom. 39). Em 1796, um outro filho de Elena foi batizado pelo próprio João Cabral, e Maria, filha de Antonio da Veiga Leme, foi novamente a madrinha (LBPSJP 1, 132v/133). Esse menino faleceu aos 3 
meses de idade (LOPSJP 1, 1797, 98). No batismo da última filha de Elena, em 1798, o padrinho foi Manoel Simões da Costa, um sapateiro branco, sem escravos. Mais uma vez, Maria, filha de Antonio da Veiga Leme, foi a madrinha (LBPSJP 1, 136v).

Ao escolher seus compadres, Dorotéia, ao que tudo indica, priorizou o amparo que a ligação com membros da elite poderia proporcionar a si e a seus filhos. Já os laços de compadrio efetuados por Elena nos sugerem a opção pelo reforço de laços de amizade com membros da comunidade de escravos e livres pobres, especialmente com a escrava Verônica, com os filhos do falecido Antonio da Veiga Leme e com a família do músico João Cabral. Aliás, embora Rita Cabral, o pai e os irmãos apareçam sempre identificados como brancos, em 1802 ela se casou com Antonio Rodrigues (LCPSJP 2, 45), identificado como pardo (LNSJP, $3^{\text {a }}$ cia, dom. 319). Ele era filho de Inácio Rodrigues e Maria de Jesus, recenseados como branco, o marido, e como parda, a esposa (LNSJP, 1802, $3^{\text {a }}$ cia, dom. 291).

Parece, enfim, que Dorotéia e Elena tinham diferentes expectativas em relação ao estabelecimento de alianças sociais por ocasião do batismo dos filhos. Como bem observou Silvia Maria Brügger, a especificidade do compadrio talvez residisse exatamente no fato de apresentar uma grande possibilidade de extensão, permitindo a criação de sólidos vínculos entre pessoas das mais diferentes condições sociais, que passavam a se reconhecer como parentes. Entre elas não haveria nenhuma implicação de ordem patrimonial, como ocorria, por exemplo, no estabelecimento de alianças matrimoniais. ${ }^{21}$

Assim, o parentesco espiritual poderia ser utilizado como estratégia para "criar laços morais com pessoas de recursos, para proteger-se a si e aos filhos", como salientou Slenes. Mas também poderia funcionar como meio de socialização de modo a formar uma comunidade escrava, como sugeriu Góes, ou, no ambiente de poucos escravos e muitos livres de cor, como era o caso da freguesia de São José dos Pinhais, uma comunidade de escravos e livres pobres.

\section{Compadrio de Antonio Guiné e EsperançA, ESCRAVOS DE MANOEl José DA CRUZ}

Esperança, escrava de Manoel José da Cruz, batizou cinco filhos em São José dos Pinhais entre 1789 e 1801. Os três primeiros eram de pais incógnitos, os demais, filhos seus com Antonio Guiné, também escravo de Manoel José da Cruz. 
O primeiro filho de Esperança foi apadrinhado por Manoel, escravo de Manoel Fernandes, morador de Paranaguá, e pela escrava Teresa, de propriedade de Rosa Maria Guedes (LBPSJP 1, 1789, 106v). Não consegui descobrir quem era Manoel Fernandes, mas sei que Rosa Maria Guedes, proprietária da madrinha, era tia materna de Margarida Angélica de Oliveira, esposa de Manoel José da Cruz. A segunda filha, Teresa, foi batizada em 1791 por Francisco, filho de Tomás João Ferreira, e por Gertrudes, filha do Capitão João da Rocha Loures (LBPSJP 1, 115), ambos sobrinhos da esposa de Manoel José da Cruz.

A terceira filha teve Tomás João Ferreira (irmão de Margarida Angélica) e sua filha Josefa (portanto, sobrinha de Margarida Angélica) como padrinhos (LBPSJP 1, 1795, 128v). Joaquim, quarto filho de Esperança e Antonio, foi batizado por Teodoro, outro filho de Tomás João Ferreira, e por Francisca do Rosário Freitas, solteira (LBPSJP 1, 1796, 132). Sei que tempos depois essa madrinha se casou com Francisco Ignácio de Andrade, pois encontrei o registro de três filhos deles (LBPSJP 2, 1798, 85v; 1799, 100v e 1801, 113v). Localizei Francisco Inácio na lista nominativa de 1798 (LNSJP, p. 7). Ele e a mulher foram registrados como brancos, e na casa viviam também um escravo e três agregados. Em 1803 o casal estava agregado na casa do vigário Theodoro José de Freitas, com os filhos Theodoro e Anna, de um e três anos, respectivamente (dom. 321). Mas Francisca logo ficou viúva, pois em 1806 contraiu segundas núpcias com João Mendes Machado (LCPSJP 2, 56v), este, recenseado em 1818 como capitão da 9a Companhia de São José, e proprietário de 13 escravos ( $9^{\mathrm{a}}$ cia, dom.1).

O último filho de Antonio e Esperança foi apadrinhado por Francisco e Rosa, filhos de Maria do Carmo, solteira (LBPSJP 1, 1801, 140v). Esta última aparece na lista nominativa de 1798 como forra e fazendeira da Fazenda Bom Jesus (p.8). Na lista nominativa de 1803 consta que era parda e lavradora (dom. 61).

Como se pode observar, tal como Elena, também Esperança convidou padrinhos dos vários estratos sociais. No entanto, o que se destaca no seu caso era a ligação que tinha com a família de Tomás João Ferreira, irmão de sua senhora, Margarida Angélica (Figura 1, a seguir). 
Figura 1 - Compadrio do casal Antonio e Esperança, escravos de Manoel José da Cruz (MJC)

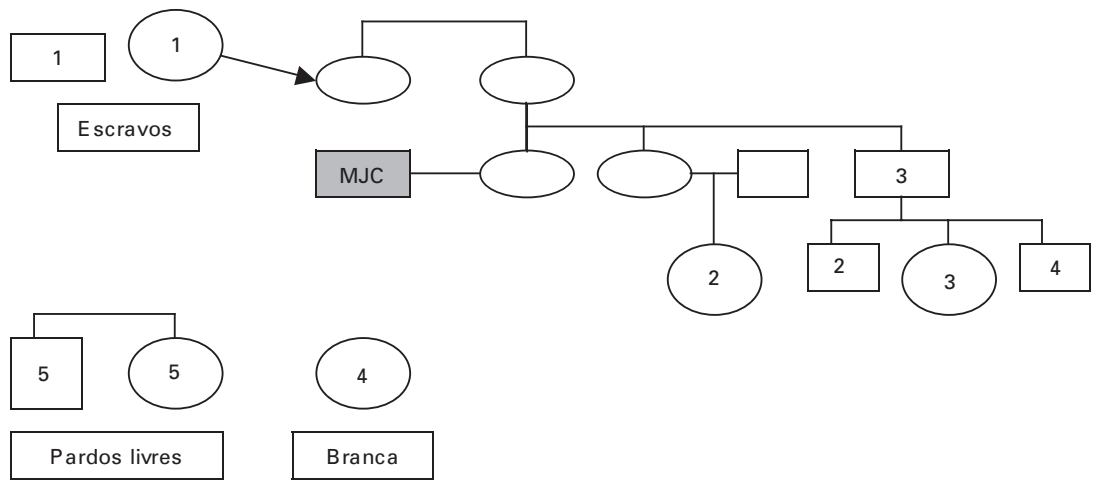

Teresa, filha de Esperança batizada em 1791, também estabeleceu laços de compadrio com a família senhorial. Ela se casou em 1805 com o escravo João, quando ambos eram propriedade de Francisco Bueno da Rocha, genro de Manoel José da Cruz. O primeiro filho do casal foi à pia batismal em 1809, e teve por padrinhos Bernardo Martins Ferreira Neto e Maria Francisca, sua mulher (LBPSJP 3, 44). O padrinho era filho de Manoel José da Cruz e, portanto, irmão da senhora. O segundo filho foi batizado em 1812, e apadrinhado por Manoel da Cruz, filho de Manoel José da Cruz (portanto, também irmão da senhora) e por Francisca, filha de Joaquim Bastos (LBPSJP 3, 62). Esta madrinha tinha parentesco com a senhora da criança batizada, pois era neta de Rosa Maria Guedes, irmã de Margarida Oliveira Leão, esta avó da senhora do casal de cativos. O terceiro filho, batizado em 1814, teve por padrinhos Manoel e Anna, também filhos do mesmo Joaquim Bastos (LBPSJP 3, 79).

Figura 2 - Compadrio do casal João e Teresa, escravos de Francisco Bueno da Rocha (FBR)

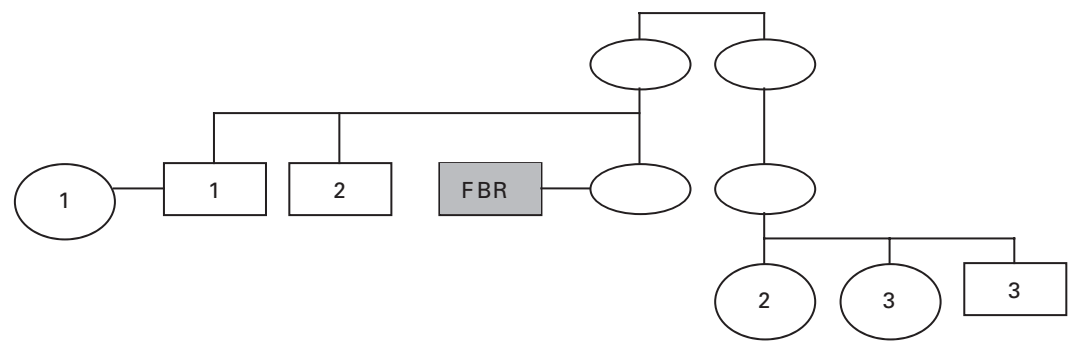


Esse tipo de vínculo com a parentela senhorial aparece de forma ainda mais marcante nos batismos dos filhos e principalmente dos netos e bisnetos do casal Antonio e Simoa e dos filhos e netos da escrava Liberata, todos eles escravos de Bernardo Martins Ferreira, que analiso nos próximos itens.

Compadrio de Antonio Angola e Simoa, escravos de Bernardo Martins Ferreira

Antonio e Simoa casaram-se em 1764 (LCPSJP 1, 15 e 15v). Por então já eram cativos de Bernardo Martins Ferreira, e embora nas listas nominativas e nos batismos dos filhos Antonio apareça identificado como Angola, no registro de seu casamento ele foi citado como Benguela. Em São José dos Pinhais não existe o registro do batismo de Feliciana, a filha mais velha, cuja filiação pude identificar pelo registro de seu casamento (LCPSJP 1, 1783, 74v e 75). Entretanto, na Figura 3, a seguir, resumi os laços de compadrio efetuados a partir do batismo dos demais filhos do casal.

Figura 3 - Compadrio do casal Antonio e Simoa, escravos de Bernardo Martins Ferreira (BMF)

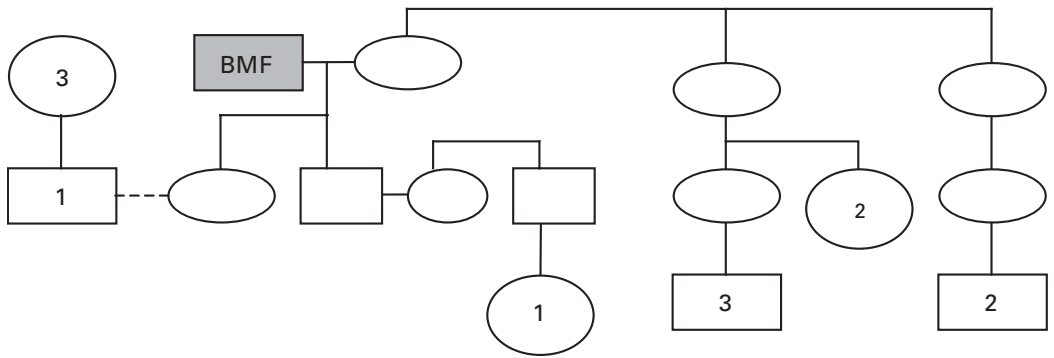

João, o primeiro filho batizado na paróquia de São José, teve como padrinhos Manoel, filho de Nazário Texeira da Cruz, e Maria, filha de Manoel Vaz Torres (LBPSJP 1, 1773, 79v). Trata-se, o primeiro, de Manoel José da Cruz, que sete anos depois se casaria com Margarida, filha de Bernardo Martins (LCPSJP 1, 1780, 167). Maria, filha de Manoel Vaz Torres, deve ser sobrinha de Maria Vaz, esposa de Tomás João Ferreira (filho de Bernardo Martins). Isso porque, de acordo com o registro de casamento de Tomás João e Maria Vaz, ocorrido em 1768, a noiva era filha de Manoel Vaz Torres. Já Maria, a ma- 
drinha, deve ser filha de Manoel Vaz Torres ( $2^{\circ}$.), filho do anterior e, portanto, irmão de Maria Vaz (LCPSJP 1, 1768, 29).

Salvador, filho de Antonio e Simoa batizado em 1776, foi apadrinhado por Francisco, filho de Pedro Antonio Moreira, e por Maria, filha do falecido João Franco Moreira (LBPSJP 1, 86). Também esses faziam parte da família senhorial. O padrinho era sobrinho-neto e a madrinha era sobrinha de Margarida Oliveira Leão, mulher de Bernardo Martins.

Os padrinhos de Águida, a última filha de Antonio e Simoa, foram Bento Ferraz Lima e Josefa Álvares Pereira, esposa de Nazário Teixeira da Cruz (LBPSJP 1,1783, 95v). Os dois últimos eram os pais de Manoel José da Cruz, então já marido de uma filha de Bernardo Martins. Bento Ferraz Lima também era sobrinho-neto de Margarida Oliveira Leão.

\section{COMPADRIO DE LIBERATA E DOS FILHOS \\ De Antonio Angola e Simoa}

Mencionei anteriormente que só pude identificar a cativa Feliciana como filha do casal Antonio e Simoa porque encontrei seu registro de casamento em São José dos Pinhais, onde se anotou sua filiação. Portanto, não é improvável que a cativa Liberata também fosse filha daquele casal, o que não se pôde comprovar por ela não ter se casado. De modo que resolvi analisar os batismos de seus filhos e netos junto com os da família de Antonio e Simoa, posto que eram escravos de um mesmo senhor. Um resumo dos laços de compadrio desta escrava encontra-se efetuada na Figura 4, a seguir.

Figura 4 - Compadrio de Liberata, escrava de Bernardo Martins Ferreira (BMF) e de sua filha Gertrudes Maria da Luz (GML)

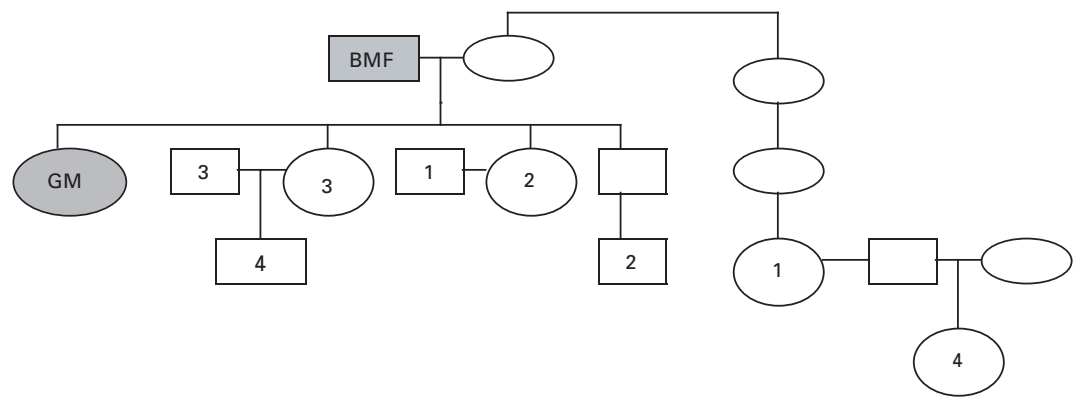


O primeiro dos quatro filhos de Liberata recebeu o nome de Joaquim e foi apadrinhado em 1783 por Manoel da Cruz Teixeira e por Luzia, filha de João Bastos Coimbra (LBPSJP 1, 96). Não é improvável que o padrinho fosse Manoel José da Cruz - filho de Nazário Teixeira da Cruz e genro de Bernardo Martins - sendo identificado de outra forma, o que não era incomum no passado, ou então era parente dele. A madrinha era neta de Rosa Maria Guedes, esta, irmã da senhora de Liberata.

Em 1784 Liberata teve seu segundo filho, a menina Lucrécia. Por então, a mãe já era escrava de Gertrudes Maria da Luz (filha de Bernardo Martins e Margarida Oliveira Leão). A criança foi batizada por Francisco Ferreira de Paula, filho de Tomás João Ferreira (portanto sobrinho de sua nova senhora), e por Margarida Angélica, irmã de sua senhora (LBPSJP 1, 98v). Em 1791 ocorreu o batismo da filha Feliciana, apadrinhada pelo Capitão João da Rocha Loures e por sua esposa Ana Ferreira, respectivamente cunhado e irmã de Gertrudes Maria da Luz (LBPSJP 1, 125v). Em 1794, o último filho, Francisco, teve por padrinhos Antonio João da Costa $\left(2^{\circ}\right)$, filho do Capitão João da Rocha Loures, e por Maria Teresa, filha de Antonio Pereira do Valle (LBPSJP 1, 125v). O padrinho era, portanto, sobrinho de Gertrudes Maria, já a madrinha era enteada de Luzia Fernandes Bastos, que apadrinhou o primeiro filho de Liberata.

Figura 5 - Compadrio do casal Joaquim e Feliciana, escravos do Capitão João da Rocha Loures (JRL)

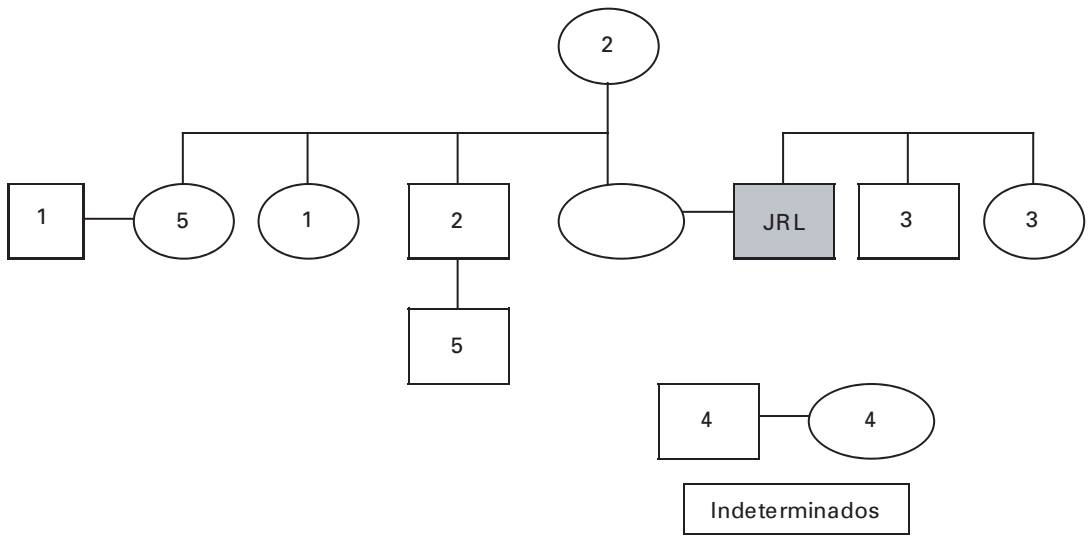


Como já indiquei, Feliciana, a filha mais velha de Antonio e Simoa, casouse em 1783 com o escravo Joaquim. Naquele momento ela e o marido eram propriedade do Capitão João da Rocha Loures, genro de Bernardo Martins. O quadro do apadrinhamento dos filhos desse casal encontra-se na Figura 5.

O filho Cipriano foi apadrinhado por Manoel José da Cruz (cunhado da senhora) e por Gertrudes, filha de Bernardo Martins, portanto, irmã da senhora (LBPSJP 1, 1784, 75v). Em seguida Joaquim e Feliciana batizaram o filho Hilário, que teve por padrinhos Tomás João Ferreira (irmão da esposa de Rocha Loures) e Margarida de Oliveira Loba ou Leão, sogra de Rocha Loures (LBPSJP 1, 1785, 101). Dois anos depois o casal levou à pia batismal o filho Inácio, apadrinhado por Miguel Arcângelo e Maria de Nazaré, irmãos de seu senhor (LBPSJP 1, 1787, 104).

O compadrio estabelecido por ocasião do batismo de Bento, penúltimo filho de Joaquim e Feliciana, distingue-se dos anteriores. Seus padrinhos foram José Paes de Almeida e sua esposa Francisca Maria do Pilar (LBPSJP 1, $1789,106)$. Infelizmente não consegui localizar esse casal nas listas nominativas. Mas encontrei seu registro de casamento (LCPSJP 2, 1786, 1), bem como o batismo de dois de seus filhos. Neles consta que José Paes de Almeida era natural da Vila de São José de Mogi Mirim, em São Paulo, e que Francisca era da freguesia, embora não houvesse referência a seus pais, nem mesmo no registro do casamento. De qualquer forma pode-se afirmar que eram gente das relações do Capitão João da Rocha Loures, proprietário de Joaquim e Feliciana, pois a primeira filha do casal foi batizada pelo próprio Capitão Rocha Loures, e por uma cunhada deste, Teresa de Jesus do Nascimento (LBPSJP 2, 1788, 26v). A segunda filha foi batizada por Miguel Arcângelo e Francisca de Paula, irmãos de João Rocha Loures (LBPSJP 2, 1790, 35).

A última filha de Joaquim e Feliciana recebeu o nome de Escolástica, e foi apadrinhada por Francisco, filho de Tomás João Ferreira, e por Margarida Angélica (LBPSJP 1, 1791, 114v), respectivamente sobrinho e irmã de sua senhora. 
Figura 6 - Compadrio do casal José e Águida, escravos de Margarida Oliveira Leão (MOL) e de sua filha Gertrudes Maria da Luz (GML)

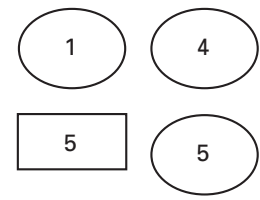

Brancos
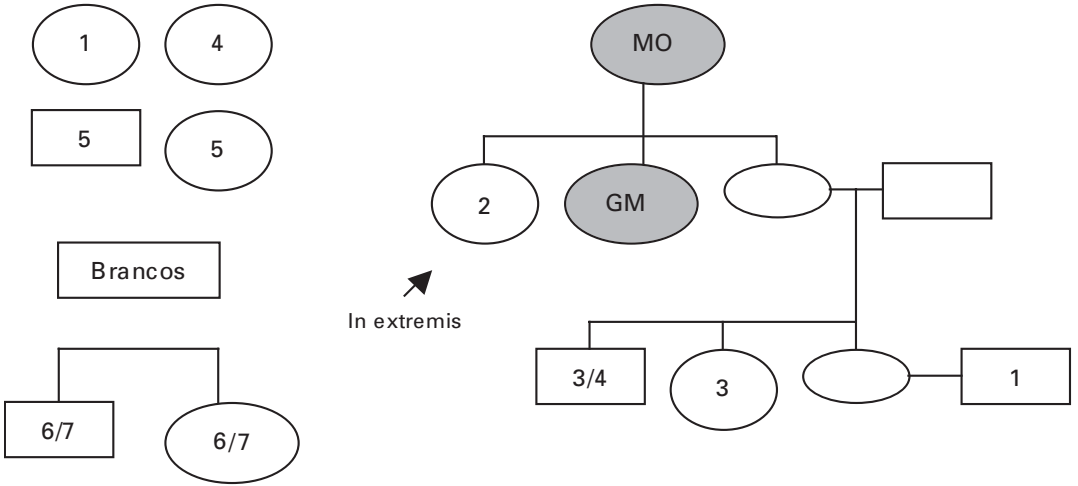

Pardos forros

Também encontrei os batismos dos filhos de Águida, a caçula do casal Antonio e Simoa. Águida havia se tornado propriedade de Gertrudes Maria da Luz (filha solteira de Bernardo Martins e Margarida Oliveira), algum tempo depois de se casar com José, escravo da mesma Gertrudes. O casal teve ao menos sete filhos, cujo quadro de apadrinhamento está resumido na Figura 6.

A primeira, a menina Josefa, nascida quando Águida ainda pertencia a Margarida Oliveira, foi batizada por José Joaquim, casado, e por Izabel de Souza, esposa de José Alvares (LBPSJP 1, 1801, 139). O padrinho era provavelmente o português José Joaquim dos Santos, casado com Anna Ferreira da Rocha, filha de João da Rocha Loures.

O segundo filho, nascido quando Águida já era propriedade de Gertrudes Maria, foi batizado in extremis por Margarida Angélica, irmã da senhora (LBPSJP 3, 1804, 6). O terceiro, Domingos, foi à pia batismal sob o apadrinhamento de João e Gertrudes, filhos do Capitão João da Rocha Loures (LBPSJP 3, 1808. 34). A menina Antonia também foi batizada por João, filho do Capitão Loures, e teve a viúva Maria Antonia por madrinha (LBPSJP 3, 1810, 49). Esta última pode ser a mesma Maria Antonia (Albuquerque), que em 1787 batizou uma filha da cativa Elena, mencionada anteriormente. Mas não há como saber, pois na lista nominativa de 1810 existem duas viúvas, ambas brancas, com o nome de Maria Antonia e sem a indicação dos sobrenomes (dom. 179 e 333). 
Antonio, nascido dois anos depois, foi apadrinhado por Manoel de Jesus e por Anna, enteada de João Mendes (LBPSJP 3, 1812, 66v). Encontrei um Manoel de Jesus, na lista nominativa de 1810, recenseado como lavrador, branco, 30 anos, e vivendo com mulher, dois escravos e uma menina parda agregada (dom. 231). João Mendes, padrasto da madrinha, era provavelmente João Mendes Machado, casado desde 1806 com Francisca do Rosário Freitas (madrinha de um filho de Antonio e Esperança em 1796). Em 1818, como já mencionei, João Mendes era capitão da $9^{a}$ Companhia de São José e proprietário de 13 escravos.

As coisas começaram a mudar para o casal José e Águida somente em 1823, quando do batismo do filho Francisco. Nele, a senhora "mandou que assentasse por forro [o menino], pois pretendia que todos ficassem forros, visto não ter herdeiro forçado nenhum" (LBPSJP 3, 155). Os padrinhos do menino foram Joaquim e Lucrécia, filhos de Liberata, também escrava de Gertrudes Maria. Naquela data Joaquim e Lucrécia já eram forros, embora a mãe deles permanecesse cativa. Por então, Lucrécia estava agregada na casa da exsenhora, e Joaquim (que adotou o sobrenome Cruz, provavelmente em homenagem ao seu padrinho Manoel José da Cruz) vivia com a mulher e os filhos em domicílio independente, porém vizinho ao de sua ex-senhora. ${ }^{22}$

Embora tivesse a sorte de ser alforriado na pia, o menino Francisco não deve ter sobrevivido, pois em 1825 José e Águida deram o mesmo nome a um outro filho, e os mesmos padrinhos (LBPSJP 3,157v). Nesse registro os pais da criança foram identificados como 'administrados' de Gertrudes Maria da Luz, logo, também eles haviam conquistado a alforria.

\section{COMPADRIO DE NETOS DE ANTONIO ANGOla E Simoa E DE UMA FILHA DE Liberata}

Escolástica, filha caçula de Joaquim e Feliciana e escrava do Capitão João da Rocha Loures, teve ao menos três filhos (Figura 7, adiante). A menina Antonia, batizada em 1811, foi apadrinhada por Joaquim José da Cruz e Reginalda da Silva, sua mulher (LBPSJP 3, 59). Joaquim José da Cruz era o filho liberto da escrava Liberata, que mencionei como padrinho dos dois últimos filhos de José e Águida. Na época em que batizaram a filha de Escolástica, porém, ele e sua esposa ainda viviam como agregados na casa da ex-senhora.

O segundo filho de Escolástica foi apadrinhado por Francisco da Rocha e por Ana, filha de João Nepomuceno (LBPSJP 3, 1814, 79v). Francisco da Rocha era casado com Gertrudes da Cruz, filha de Manoel José da Cruz e Mar- 
garida Angélica, portanto, sobrinha da senhora de Escolástica. A madrinha era sobrinha do Capitão João da Rocha Loures.

Em 1820 nasceu o último filho de Escolástica, cujos padrinhos foram Joaquim Pereira, casado, e Gertrudes da Cruz, casada com Francisco da Rocha (LBPSJP 3, 120v). Gertrudes, já se sabe, era sobrinha da senhora de Escolástica. O padrinho é provavelmente Joaquim Pereira do Valle, irmão de uma nora do Capitão João da Rocha Loures.

Figura 7 - Compadrio de Escolástica, escrava do

Capitão João da Rocha Loures (JRL)
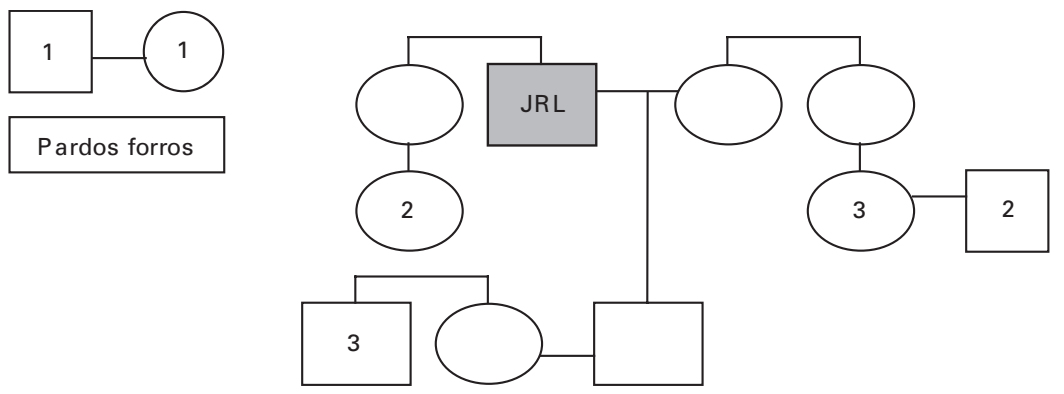

Feliciana, filha de Liberata nascida em 1791, casou-se em 1809 com Joaquim Manoel, pardo livre oriundo de São Francisco, em Santa Catarina (LCPSJP 1, 93). Desde o casamento, Joaquim Manoel tornou-se agregado de Gertrudes Maria, proprietária de Feliciana. Na Figura 8, a seguir, resumi a história do apadrinhamento de seus filhos.

Figura 8 - Compadrio do casal Joaquim Manoel (forro) e de Feliciana, escrava de Gertrudes Maria da Luz (GML)
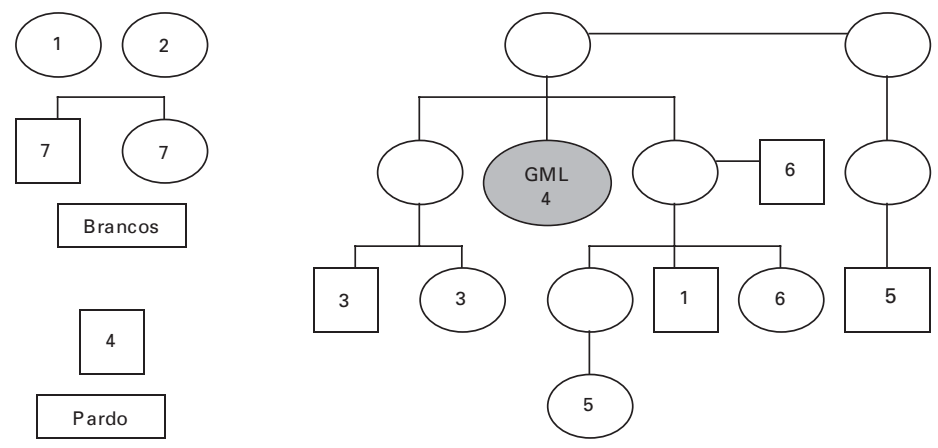
O primeiro recebeu o nome de José. Embora o pai fosse livre, o padrinho foi escolhido dentro da família senhorial: o jovem João, filho do Capitão João da Rocha Loures (portanto sobrinho de Gertrudes Maria da Luz). A madrinha foi Apelônia Ribeiro, casada com José Simões (LBPSJP 3, 1810, 49). A família de Apelônia está registrada na lista de 1810 no domicílio 366 (e o domicílio de Gertrudes era o 360). José Simões era lavrador e o casal vivia com sete filhos, sem escravos ou agregados. Foram identificados como brancos.

Em 1813 Joaquim Manoel e Feliciana batizaram um rebento com o nome de Joaquim. No registro o pai é citado como forro, e a mãe permanece escrava de Gertrudes. O menino teve apenas madrinha: Anna Rita, filha solteira de Francisco Inácio, já falecido (LBPSJP 3, 72v). Certamente é a mesma Anna que batizou um filho de José e Águida em 1812, filha de Francisca do Rosário de Freitas.

Em 1818 nasceu Fortunato, o terceiro filho do casal. No registro foi anotado que por então a mãe estava forra, mas que o menino permaneceria cativo de Gertrudes Maria da Luz. No entanto, o pároco indicou que "quando se baptizou, o pai o forrou, e a mesma Senhora me disse estava forro". Os padrinhos do menino foram Miguel e Maria, filhos solteiros de Manoel José da Cruz, ou seja, sobrinhos da senhora (LBPSJP 3, 101).

Joaquim Manoel e Feliciana tiveram ainda mais quatro filhos. Em 1820 nasceu Silvestre. Embora no registro de batismo do filho anterior a mãe tenha sido citada como forra, neste ela aparece como escrava. No registro o pároco anotou que "a Senhora me disse que forrava o dito Silvestre por ser seu afilhado, já quando o livrou na pia me disse que o forrava, e deixava forro". $\mathrm{O}$ outro padrinho da criança era Joaquim Ribeiro da Silva, solteiro (LBPSJP 3, 119). Em 1818 existe o registro de apenas um homem com o nome de Joaquim Ribeiro em São José dos Pinhais (LNSJP, 9ª cia, dom. 18). Era pardo, com 22 anos, natural de Antonina. Vivia com a mulher, Rosa, de 16 anos, e plantava para comer.

Em 1824, no registro de batismo de Mateus, novamente Feliciana foi identificada como escrava, e a "Senhora mandou assentar por forro" [a criança]. Os padrinhos do menino foram Joaquim Bastos e Rosária (LBPSJP 3, 152). Ele deve ser Joaquim Bastos Coimbra, neto de uma irmã de Margarida Oliveira Leão (esta, mãe de Gertrudes Maria da Luz). Pode ser que a madrinha, Rosária, fosse Rosária da Rocha, filha de José Joaquim dos Santos, o qual havia batizado um filho de José e Águida em 1801 e era genro do Capitão João da Rocha Loures.

Em 1826 ocorreu o batismo de Hermenegildo, no qual a mãe foi identifi- 
cada como forra. Nessa época o casal já vivia em domicílio autônomo (LNSJP, 1824,33 ), porém próximo ao da ex-proprietária de Feliciana (LNSJP, 1824, 25). Aparentemente os dois primeiros filhos do casal, que não foram alforriados ao nascer, por então também estavam livres. Os padrinhos de Hermenegildo foram o Capitão João da Rocha Loures e sua filha Gertrudes (LBPSJP 3, 165). Em 1828 nasceu o último filho. No registro os pais foram identificados apenas como pardos, e o menino, Pedro, foi apadrinhado por Matias Carneiro Mendes de Sá e sua irmã Luiza Maria de Sá, filhos do Capitão Manoel Mendes Leitão (LBPSJP 3, 178). Esse capitão era uma das pessoas mais proeminentes do lugar e em 1824 foi recenseado como proprietário de fazendas de criar, mantendo em São José dos Pinhais 17 escravos (LNPSJP, 1824, $3^{\mathrm{a}}$ cia, 7).

\section{CONTROLE SENHORIAL, COMUNIDADE DE ESCRAVOS E DE}

PARDOS E NEGROS LIVRES E REPRODUÇÃO DA HIERARQUIA SOCIAL

Mencionei anteriormente que em seu estudo sobre batismos de escravos de Curitiba, Schwartz destacou que raramente os padrinhos eram os senhores ou seus parentes. O mesmo quadro se desenhou na Bahia, por Gudeman e Schwartz, e em Minas Gerais, por Higgins, e por outros autores. Na interpretação desses padrões, Schwartz reitera sua tese da incompatibilidade entre propriedade escrava e parentesco espiritual, bem como põe em dúvida o uso do compadrio para reforçar as relações paternalistas entre senhores e seus cativos.

Acredito que as relações de compadrio até aqui recuperadas me permitem tecer algumas considerações sobre essa questão. A primeira delas é que muito dificilmente o parentesco do padrinho de um escravo é revelado em estudos que utilizam como fonte apenas registros de batismo, posto que neste tipo de documento eclesiástico nomeava-se somente o cônjuge ou o pai dos padrinhos, e isso quando a madrinha era casada ou quando o/a padrinho/madrinha era solteiro/a. De modo que em geral o parentesco que se pode levantar é o que unia marido e mulher, e pais e filhos (quando estes eram solteiros). Nos casos por mim expostos, encontram-se com mais freqüência outros vínculos parentais, especialmente sobrinhos, irmãos e cunhados, e mesmo parentes mais distantes.

Assim, tem razão Stuart Schwartz quando afirma a incompatibilidade entre propriedade escrava e parentesco espiritual. De fato, raramente o senhor batizava seus escravos e, ao menos nos casos aqui vistos, tampouco os 
seus filhos e genros (prováveis herdeiros dos cativos) o fizeram. Creio ser preciso, contudo, relativizar sua tese de que o compadrio não era utilizado como reforço das relações paternalistas. É preciso admitir ao menos algum grau de controle dos senhores sobre a socialização de seus cativos, conforme se evidencia nas recorrentes ligações de compadrio dos escravos de São José com membros da parentela senhorial.

Parece que esse mesmo quadro estava presente quando se tratava de casais mistos, isto é, aqueles em que um dos cônjuges era escravo e o outro forro ou livre. Revejam-se, nesse sentido, as relações de compadrio efetivadas pelo casal Joaquim Manoel e a escrava Feliciana (cf. Figura 8).

Esse foi também o caso de Joaquim Antonio Barbosa e sua mulher Quitéria. Esse casal foi unido pela Igreja em 1779 (LCPSJP 1, 59v). O marido era filho de uma ex-administrada de José de Aguiar, e a esposa era escrava de Antonio de Souza Pereira. Quitéria nasceu escrava de Felipe Pereira de Magalhães e de Rosa Maria Guedes, esta, irmã de Luzia Cardoso Leão, que por sua vez era avó de Coleta Maria, a esposa de Antonio de Souza Pereira. ${ }^{23}$ Quitéria faleceu precocemente (LOPSJP $1,1785,87 \mathrm{v}$ ), de modo que o casal teve apenas dois filhos.

Em maio de 1780 Joaquim Antonio e Quitéria batizaram Bento, apadrinhado por Manoel, filho solteiro de Manoel Vaz Torres, e por Maria, filha solteira de Felipe Valente, de Curitiba (LBPSJP 1, 92 e 92v). Sobre a madrinha não tenho informações, mas Manoel, filho de Manoel Vaz Torres, tinha parentesco por afinidade com os Cardoso Leão, pois, como já mencionei antes, sua irmã Maria Vaz Torres de Araújo era casada com Thomas João Ferreira, filho de Margarida Oliveira Leão (irmã de Rosa Maria Guedes).

Em 1784, no batismo do filho Serafino, os laços com a família do proprietário de Quitéria se consolidaram. O menino foi apadrinhado por Gertrudes Maria da Luz e por João Rocha Loures (LBPSJP 1, 98v). Como se sabe, eles eram, respectivamente, filha e genro de Margarida Oliveira Leão (também irmã de Rosa Maria Guedes).

O mesmo tipo de relação com o senhor parece ter ocorrido com Antonio, escravo de Paulo da Rocha, e Gertrudes Leme, filha dos ex-administrados Gregório Leme e Domingas do Rosário. Eles se casaram em 1783 (LCPSJP $1,75)$ e tiveram ao menos seis filhos.

O primeiro filho foi apadrinhado pelo casal proprietário de Antonio (LBPSJP, 1784, 99). Em 1789 foi batizada a menina Leonor, que teve como padrinhos Jerônimo Caixes e Rita, filha de Bonifácio da Silva (LBPSJP 1, 106v). Em 1792 nasceu Maria. Os padrinhos foram os mesmos Bonifácio da Silva e 
sua filha Rita (LBPSJP 1, 115v). Em 1793 a filha Izabel foi apadrinhada por Francisco da Cunha Bueno e Izabel Maria, ambos casados e da freguesia (LBPSJP 1, 120v). Em 1795 o pequeno Joaquim foi apadrinhado por João Bueno e Ângela Maria sua mulher (LBPSJP 1, 130). Em 1797, o menino Manoel foi apadrinhado por Manoel Pires e Anna, filha solteira de Joanna da Rocha (LBPSJP 1, 133). Por fim, em 1800 foi batizado o menino João, sob o apadrinhamento do alferes Luis Cardoso, solteiro, e da mesma Anna da Rocha, agora casada com José Joaquim (LBPSJP 1, 138V/139).

Mais uma vez, tem-se aqui a indicação da existência de laços entre o escravo e a família de seu proprietário, sugeridos pelo grande número de padrinhos com sobrenomes Bueno e Rocha, muito provavelmente familiares do casal Paulo da Rocha e Maria Buena da Rocha. Além disso, novamente constata-se o predomínio de laços de compadrio com pessoas livres.

Todavia, aqui o destaque, a meu ver, foi o apadrinhamento de um filho de Antonio por seus senhores. Embora a criança fosse livre (como a mãe, Gertrudes), o fato é que a partir de então o escravo Antonio se tornou compadre de seus proprietários. Mas essa pode ter sido a interpretação apenas do cativo, que talvez pensasse ser esse um caminho possível para a obtenção de sua alforria (o que não aconteceu). Relembrando que Gertrudes vivia agregada na casa, pode-se supor que, para Paulo da Rocha, batizar um filho livre de seu cativo não seria fonte de constrangimento, ao contrário, poderia ser uma forma de reforçar ou consolidar sua autoridade sobre a família do escravo. Um ponto de vista que se aproximaria daquele observado por Stuart Schwartz, na passagem do século XVII para o XVIII em Curitiba, acerca do apadrinhamento senhorial de filhos de administrados, citado no início do artigo. Eu acrescentaria, no entanto, que à época do predomínio da escravidão negra na região, talvez os escravistas do lugar tenham mantido o compadrio como forma de controle de seus dependentes livres (antes os administrados de origem indígena, agora os filhos livres de seus escravos).

A despeito dessas considerações, acredito que não se pode aceitar que o controle senhorial implicasse a anulação de qualquer iniciativa escrava. Assim, se o grande número de padrinhos aparentados com o senhor do batizando sugerem que o cálculo escravista também vigia nesse assunto, é igualmente certo que as preferências dos cativos contavam. Relembre-se, nesse sentido, que a escrava Esperança estabeleceu laços de compadrio basicamente com a família de Tomás João Ferreira, irmão de sua senhora Margarida Angélica (cf. Figura 1). Igualmente, que alguns parentes foram padrinhos de vários escravos, especialmente o jovem Francisco (filho de Tomás João Ferreira), Marga- 
rida Angélica (esposa de Manoel José da Cruz) e João (filho de João da Rocha Loures), este, padrinho de dois filhos de José e Águida, escravos de Gertrudes Maria da Luz.

Porém, alguns parentes nunca foram chamados para apadrinhar: Bernardo Martins Ferreira e Margarida Oliveira Leão tiveram ao menos oito filhos, porém apenas quatro deles (ou seus cônjuges e filhos) em algum momento apadrinharam os descendentes dos escravos de seus pais. Dentre os quatro filhos que não apadrinharam, ao menos um vivia em São José dos Pinhais: Manoel Ferreira de Melo, que aparece chefiando domicílio (com sua família e alguns escravos) no mínimo em quatro listas nominativas no período. ${ }^{24}$

Além disso, por vezes esses escravos tornaram-se compadres de pessoas com parentesco bastante indireto com o proprietário dos pais da criança batizada. Foi o caso de Liberata, cujo primeiro filho teve como madrinha uma sobrinha-neta de sua senhora naquele momento. Quando já era propriedade de Gertrudes Maria da Luz, Liberata chamou, para apadrinhar um seu outro filho, a enteada daquela madrinha (cf. Figura 4) Veja-se também o caso de Escolástica, escrava do Capitão João de Rocha Loures. Um filho desta cativa teve por padrinho o irmão de uma nora do Capitão. Finalmente, um dos filhos do forro Joaquim Manoel e sua esposa Feliciana, escrava de Gertrudes Maria da Luz, foi apadrinhado por Joaquim Bastos Coimbra, primo de segundo grau da proprietária de Feliciana, e os filhos dos escravos João e Teresa foram apadrinhados por outros dois filhos desse mesmo Joaquim Bastos (cf. Figura 7).

Esses cativos também puderam estabelecer laços com não-parentes de seus proprietários, muitos deles da elite, inclusive de outras vilas, como foi o caso das escravas de Antonio dos Santos Teixeira, cujos vínculos com pessoas da vila da Lapa talvez fossem anteriores ao que as ligava ao senhor. Casos como esses sugerem que os escravos não se pautavam apenas por estratégias visando intermediação de um livre nos conflitos com o senhor, ou a viabilização da comunidade de cativos. Tais escolhas podem estar relacionadas à valorização de antigos laços sociais e afetivos. Num período em que o deslocamento de uma vila para outra era complicado e demorado, a vinda dos filhos de José dos Santos Pacheco, da Lapa para São José dos Pinhais, apenas para batizar um filho da escrava Dorotéia, a meu ver demonstra que aqueles laços eram igualmente valorizados por eles. O mesmo se pode dizer dos padrinhos e do vigário (todos da Lapa) que participaram do batismo de outra escrava de Antonio dos Santos Teixeira, em São José dos Pinhais.

Mas a constituição de alianças com homens livres podia, de fato, ser um recurso importante nessa sociedade extremamente hierarquizada, onde es- 
cravos, forros e livres de cor eram vistos como pessoas de "menor qualidade". Um exemplo da importância desses laços está na trajetória do "cabra forro" Vicente Francisco. Pude reconstruir sua história desde a sua união matrimonial, em 1777, com Antonia, escrava de Manoel Gonçalves Padilha (LCPSJP $1,1777,53 v)$. As testemunhas de seu casamento foram o senhor de Antonia e Diogo Bueno Barbosa. Vicente e Antonia tiveram ao menos três filhos. Em dezembro de 1777 batizaram Antonio, em cujo registro consta o apadrinhamento de Paulo da Rocha e Maria Buena, sua mulher (LBPSJP 1, 88v). A filha Rita foi batizada em outubro de 1780, e apadrinhada por Amaro e Anna, ambos filhos de Antonio da Veiga de Godoy (LBPSJP 1, 92v).

Graças à preservação de um processo de Autos de Livramento, soube que Vicente Francisco esteve preso por furto de uma vaca a Francisco Bueno da Cunha e Pedro Machado Fagundes, "a mando de Manoel Gonçalves Padilha”. Em 1785 o próprio Francisco Bueno da Cunha testemunhou em favor do réu, dizendo que se equivocara, pois teria sido outro o autor do furto. Dentre as testemunhas de defesa estavam Antonio da Veiga de Godoy e Diogo Bueno Barbosa. ${ }^{25} \mathrm{O}$ primeiro, como se viu, era o pai dos padrinhos de um dos filhos de Vicente Francisco, e o segundo fora testemunha de seu casamento.

Após esse incidente com a justiça, Vicente Francisco teve mais uma filha, que em 1788 foi batizada com o nome de Anna. Ela teve como padrinhos Diogo Bueno Barbosa e novamente Anna Clara, filha de Antonio da Veiga de Godoy (LBPSJP 1, 92). Ou seja, depois de absolvido da acusação de roubo, Vicente buscou reiterar os laços de compadrio com seus defensores, por ocasião do nascimento da última filha. Nesse sentido, esses registros nos permitem depreender que nessa sociedade o compadrio podia funcionar no sentido de gerar não apenas alianças entre as famílias de cativos e administrados e as de seus senhores, mas também estabelecer outros laços sociais, os quais, no caso presente, mostraram sua eficácia num momento de dificuldade.

A observação das idades dos padrinhos é outro indício a sugerir que os cativos participavam na escolha das pessoas com quem estabeleceriam laços de compadrio. Tomando apenas os batismos de filhos, netos e bisnetos de Antonio Angola e Simoa, e de filhos e netos de Liberata, tem-se que 24 dos 56 padrinhos foram citados como "filhos de alguém" (11 padrinhos e 13 madrinhas). Foi possível descobrir as idades exatas ou aproximadas de 19 deles; ${ }^{26}$ 14 (seis homens e oito mulheres) tinham menos de 25 anos no momento do batismo, dos quais, seis tinham menos de 18 anos. Além disso, muitos dos padrinhos e madrinhas identificados como casados eram jovens com menos de 25 anos. A meu ver, tal quadro reflete a preocupação dos escravos em assegu- 
rar que sua prole teria protetores e aliados ao longo da maior parte da vida, ou ao menos até que pudesse realizar suas próprias alianças.

Finalmente, destaco que, a despeito da importância estratégica do compadrio com membros da parentela senhorial e da elite branca, esses escravos nunca deixaram de se relacionar com outros cativos, com forros, com livres de cor, e mesmo com brancos pobres. Assim foi com Elena, que teve por compadres os escravos Agostinho, Felipe e Verônica, o 'bastardo' Salvador Siqueira e sua filha, os irmãos José Leonel e Maria, e o músico João Cabral e sua filha. Assim foi com Esperança, que criou vínculos com os cativos Manoel e Teresa e com a família da parda Maria do Carmo. Do mesmo modo, por ocasião dos batismos dos filhos de Escolástica (em 1811) e de José e Águida (em 1823), apadrinhados por Joaquim José da Cruz e sua mulher Reginalda, o primeiro, e pelo mesmo Joaquim José com sua irmã Lucrécia, o segundo. Estes dois últimos batismos confirmam os laços que as uniam a Joaquim José e Lucrécia desde quando estes ainda eram escravos de Gertrudes Maria da Luz.

Esse foi o caso, igualmente, de Joana, escrava de José Teixeira da Cruz. Ela era casada com o pardo forro Luciano da Rocha Dantas, e também vivia em São José dos Pinhais (LCPSJP 2, 1831, 182). Antes de se unir a Luciano, Joana teve três filhos. Em 1819 seu filho Miguel foi batizado por Joaquim Manoel, casado, e por Lucrécia, escrava da nossa conhecida Gertrudes Maria da Luz (LBPSJP 3, 111v). A madrinha é, evidentemente, a filha da escrava Liberata, que pouco tempo depois conquistaria a liberdade (conforme vimos em item anterior). O padrinho era o cunhado livre dessa escrava, marido de Feliciana, a outra filha de Liberata.

O segundo filho de Joanna, a menina Izabel, foi batizada em 1824 por José, escravo de Pedro Teixeira, e por Luciana, escrava de Francisco Franco (LBPSJP 3, 144v). Não tenho certeza de quem seja Francisco Franco, mas Pedro Teixeira, filho de Nazário Teixeira da Cruz, era provavelmente parente do senhor de Joana.

Somente quando teve o terceiro filho Joanna convidou pessoas livres para apadrinhar. O menino Antonio teve por padrinhos Miguel João, solteiro, e Rosa Machada, casada (LBPSJP 3, 1829,190v e 191). Sobre a madrinha não consegui qualquer informação, mas o padrinho deve ser Miguel João Carvalho $\left(2^{\circ}\right)$, neto do primeiro, que era irmão de João da Rocha Loures.

Não consegui localizar o casal Francisco das Chagas Cruz e Saturnina Alvares Pereira, que batizou Gertrudes, a primeira filha de Luciano com Joana (LBPSJP 3, 1832, 247). Mas o filho nascido em 1833, Amâncio, foi batizado por Joaquim José da Cruz e por Felicidade Alvares (LBPSJP 3, 268). O padri- 
nho era, como se sabe, o filho forro da nossa conhecida escrava Liberata. Joanna foi declarada forra nesse registro de batismo, mas seu filho permanecia escravo de José Teixeira da Cruz.

Em 1838 o casal novamente batizou uma filha, Laurinda, apadrinhada por Francisco Franco de Oliveira e sua mulher Izabel Ferraz (LBPSJP 4, 113). O padrinho talvez seja o mesmo Francisco Franco que apadrinhou Izabel em 1824. E lembro que Bernarda, filha de Nazário Teixeira da Cruz, se casou com Bento Ferraz Lima em 1782 e teve, entre outros filhos, uma menina de nome Izabel (LBPSJP 4, fl. 190v), que pode ser a madrinha.

Os dados aqui analisados, pode-se dizer, tendem a confirmar as teses dos mais recentes estudos, comentadas no início do artigo, de que o compadrio era uma aliança utilizada de diversas maneiras por escravos e libertos. Foi um instrumento efetivo na formação e consolidação de uma comunidade de escravos e livres de cor, mas também ligava essa população com a sociedade branca de todos os estratos sociais, e ao menos em São José dos Pinhais, com a parentela senhorial.

Sabemos que a utilização histórica do rito do compadrio transcende seu significado religioso. Estar compadre de alguém, segundo o dicionarista Morais e Silva (1789), também significava estar em boa amizade. Relatos coevos aludem à extrema importância dada na sociedade colonial às relações de compadrio, havendo registro de parentes consanguíneos preferirem se intitular compadres, dado o prestígio dessa relação. ${ }^{27}$

Enfim, o compadrio com uma pessoa de status social mais alto poderia constituir uma aliança decorrente da "necessidade, num mundo hostil, de criar laços morais com pessoas de recursos, para proteger-se a si e aos filhos". ${ }^{28}$ Sobre o apadrinhamento de escravo por parentes do senhor poder-se-ia acrescentar que, da perspectiva do pai ou da mãe da criança, seria estratégico ter como aliado alguém que, embora não pertencesse à casa do senhor, era seu parente, portanto suficientemente próximo para poder interferir em caso de conflitos.

Mas o compadrio também se constituía em uma aliança que sacramentava a paz (ou dirimia as diferenças). ${ }^{29}$ Dito de outro modo, a casa de um compadre passava à condição de território amigo, ou familiar, onde o outro compadre e sua família (escravos ou não) teriam trânsito livre. Dessa perspectiva, o parentesco ritual com membros de famílias escravistas permitia a cativos, forros, e a pardos e negros livres a comunicação e a convivência com a escravaria e os agregados das casas senhoriais, muitos deles seus parentes.

Assim, sem desconsiderar o conteúdo paternalista implícito naqueles la- 
ços, talvez seja possível ao menos sugerir que o compadrio escravo também pudesse ser utilizado para estreitar os laços com as casas em que seus parentes e amigos viviam como cativos ou como agregados. Dessa perspectiva, constituir alianças com escravistas e com a parentela do senhor seria um outro caminho para a viabilização de uma comunidade de cativos nessa freguesia de predomínio de pequenas escravarias.

Entendendo o compadrio desta forma, tem-se um testemunho de sua eficácia no exemplo de Antonio e Simoa. Através do compadrio, entre 1773 e 1823 esse casal, suas duas filhas (Feliciana e Águida) e a neta Escolástica estabeleceram laços com 21 casas do vilarejo, sem contar que ao longo do tempo muitos dos padrinhos, filhos dos chefes dessas casas, se casaram e constituíram domicílio próprio, ampliando ainda mais o leque de relações dessa família de cativos.

Daquelas 21 casas originais, mais ou menos à época dos batismos em 16 delas havia escravos e/ou agregados. Somando-se os escravos das casas em que viviam pessoas que batizaram membros da família cativa até 1799, calculei que eles variaram entre 35 e 45 cativos. Nas casas em que viviam pessoas com laços de compadrio com a família, estabelecidos nas primeiras décadas do século XIX, encontravam-se ao menos cinco agregados e entre 35 e 40 escravos. $^{30}$

Por fim, creio que o conjunto de inferências aqui realizadas permite acrescentar algo mais. A meu ver, ainda que o estabelecimento de relações de compadrio com pessoas de status superior pudesse funcionar bem na busca de proteção social e mesmo como mecanismo de manutenção e de ampliação de uma comunidade de negros e pardos, o fato é que aquele privilegiamento sobretudo da parte de cativos de pequenas escravarias e da grande massa de pardos e negros livres e pobres — acabou por reforçar, senão criar, o componente de dominação/submissão da relação, bem como ajudou a debilitar o caráter igualitário que o parentesco espiritual tridentino também pressupunha. No entanto, somente funcionando desta maneira o compadrio - mais do que o casamento - promovia o estreitamento das relações entre escravos e proprietários, entre livres e cativos, entre negros, pardos e brancos.

Por tudo isso, no Brasil escravista - que historicamente se caracterizou pela alta disseminação da propriedade escrava (isto é, pela alta freqüência de pequenos escravistas mesmo em regiões de plantation) e pela forte presença de forros e livres de origem africana e/ou indígena na sua população - o parentesco ritual foi decisivo no peculiar processo de produção e reprodução 
de uma sociedade que, como nos mostrou Gilberto Freyre, se misturava sem deixar de preservar as diferenças.

\section{NOTAS}

${ }^{1}$ Este artigo é uma versão resumida de um capítulo de minha tese de doutorado, A trama das vontades: negros, pardos e brancos na produção da hierarquia social. (São José dos Pinhais - PR, passagem do XVIII para o XIX), defendida, em abril de 2006 no Programa de Pós-graduação em História Social da UFRJ, sob orientação do Prof. Dr. João Luis Ribeiro Fragoso.

${ }^{2}$ GUDEMAN, Stephen \& SCHWARTZ, Stuart. Purgando o pecado original: compadrio e batismo de escravos na Bahia no século XVIII, In: REIS, João José (Org.) Escravidão e invenção da liberdade. Estudos sobre o negro no Brasil. São Paulo: Brasiliense, 1988.

${ }^{3}$ Por exemplo: FERREIRA, Roberto Guedes. Na pia batismal. Família e compadrio entre escravos na Freguesia de São José do Rio de Janeiro (Primeira Metade do Século XIX). Dissertação de mestrado. PPGHIS-UFF, 2000; NEVES, Maria de F. Rodrigues das. Ampliando a família escrava: compadrio de escravos em São Paulo do século XIX. In: História e população. São Paulo: Abep/Iussp/Celade, 1989; BOTELHO, Tarcísio R. Batismo e compadrio de escravos: Montes Claros (MG), século XIX. Locus Revista de História. Juiz de Fora: Ed. UFJF, 1997, v.3, p.108-15; FARIA, Sheila de Castro. A Colônia em Movimento: fortuna e família no cotidiano colonial. Rio de Janeiro: Nova Fronteira, 1998; BRÜGGER, Silvia M. J. Minas patriarcal: família e sociedade (São João del Rei, Séculos XVIII e XIX). Niterói, 2002. Tese de doutorado - UFF, cap. 5.

${ }^{4}$ SLENES, Robert W. “Senhores e subalternos no Oeste Paulista”. In: ALENCASTRO, Luiz Felipe de (Org.) História da vida privada no Brasil. Império: a corte e a modernidade nacional. São Paulo: Companhia das Letras, 1997, p.271.

${ }^{5}$ BRÜGGER, Silvia M. J., op. cit., 2002, cap. 5.

${ }^{6}$ José Roberto Góes, analisando a Freguesia de Inhaúma, no Rio de Janeiro, entre 1816 e 1842, afirma que $65 \%$ dos padrinhos de escravos eram da mesma condição, $25 \%$ eram libertos e 10\% eram livres (1993). GÓES, José Roberto. O cativeiro imperfeito. Um estudo sobre a escravidão no Rio de Janeiro da primeira metade do século XIX. Vitória (ES): SEJC/SEE, 1993. Ana Lugão Rios, abordando os batismos de cativos, entre 1872 e 1888, em Paraíba do Sul, encontrou cerca de 40\% de padrinhos livres e mais de 57\% de escravos, sendo os padrinhos forros absolutamente minoritários. RIOS, Ana Maria Lugão. Família e Transição. Famílias negras em Paraíba do Sul 1872-1920. Dissertação de mestrado, PPGHIS-UFF, 1990, p.56-9.

${ }^{7}$ GÓES, José Roberto, op. cit., 1993.

${ }^{8}$ SLENES, Robert W. "Senhores e subalternos no Oeste Paulista". In: ALENCASTRO, Luiz 
Felipe de (Org.) História da vida privada no Brasil. Império: a corte e a modernidade nacional. São Paulo: Companhia das Letras, 1997.

${ }^{9}$ COSTA, Iraci del Nero \& GUTIÉRREZ, Horácio. Paraná - mapas de habitantes 17981830. São Paulo: IPE/USP-Finep, 1985, passim.

${ }^{10}$ Lista Geral da freguesia do Patrocínio de São José da vila de Curitiba (1782). Cópia do acervo do Cedope-UFPR, originais no Arquivo do Estado de São Paulo.

${ }^{11}$ COSTA \& GUTIÉRREZ, op. cit., 1985, p.65 e 183.

${ }^{12}$ Listas Nominativas de Habitantes de São José dos Pinhais, 1782, 1803 e 1827. Cópias Cedope-UFPR, originais no Arquivo do Estado de São Paulo.

${ }^{13}$ LUNA, Francisco Vidal. Casamento de escravos em São Paulo: 1776, 1804, 1829, p.22636. In: NADALIN, MARCILIO \& BALHANA. História e população: estudos sobre a América Latina. São Paulo: Abep/Iussp/Celade, 1990, p.227-9.

${ }^{14}$ SCHWARTZ, Stuart B. Escravos, roceiros e rebeldes. Bauru (SP): Edusc, 2001, p.223-5.

${ }^{15}$ SCHWARTZ, Stuart B., op. cit., 2001, p.220-2.

${ }^{16}$ Livro 1 de batismos, fl. 97. Arquivo da Paróquia de São José dos Pinhais (PR). Daqui em diante as referências aos registros de batismos, casamentos e óbitos dessa paróquia aparecerão no texto, entre parênteses, identificadas pelas siglas LBPSJP (batismo), LCPSJP (casamento) e LOPSJP (óbito), seguidas do número do livro, do ano do registro (quando o ano não estiver citado antes no texto) e do número da folha.

${ }^{17}$ Todas as informações do artigo referentes aos laços de parentesco dos escravistas foram obtidas por meio da consulta à genealogia da família Rocha Loures, documentada e organizada pelo Prof. Dr. Hélio Rocha (de Curitiba), a quem agradeço por disponibilizá-la.

${ }^{18}$ Livro de registro de comerciantes e artesãos, Câmara de Vereança de Curitiba, 1765 a 1784. Cópia Cedope-UFPR, originais no Arquivo da Câmara Municipal de Curitiba (PR).

${ }^{19}$ Lista Nominativa de São José dos Pinhais de 1790, p.26. Cópia do acervo do CedopeDehis/UFPR, originais do Arquivo do Estado de São Paulo. Daqui em diante as referências de listas nominativas serão colocadas no texto, entre parênteses, identificadas pela sigla LNSJP, seguida do ano, do número da companhia de ordenanças (sempre que existir a divisão) e da página (ou do número do domicílio recenseado, nos casos em que os fogos aparecem numerados no original).

${ }^{20}$ Lista Nominativa de Habitantes de Santo Antonio da Lapa, 1798, domicílio 86. Cópia Cedope-Dehis/UFPR, originais no Arquivo do Estado de São Paulo.

${ }^{21}$ BRÜGGER, Silvia M. J., op. cit., p.367.

${ }^{22} \mathrm{Na}$ lista nominativa de 1824 a casa de Gertrudes Maria da Luz era a de número 25, e a de Joaquim Cruz a de número 27.

${ }^{23}$ Autos de Casamento de Joaquim Antonio Barbosa e Quitéria, escrava, 1779. Original no 
Arquivo Metropolitano Dom Leopoldo Duarte da Cúria Metropolitana de São Paulo. Rolo 15, microfilme. Cópia do acervo do Cedope - Dehis/UFPR.

${ }^{24}$ Listas nominativas de São José dos Pinhais de 1781 (p.10), 1783 (dom. 29), 1790 (p.38) e 1803 (dom. 15).

${ }^{25}$ Autos de Livramento, 1785, Ouvidoria geral de Paranaguá, 26p., JP1433 Cx. 69, Arquivo Público do Paraná.

${ }^{26}$ Nos registros de batismo da paróquia ou nas listas nominativas.

${ }^{27}$ VAINFAS, Ronaldo (Dir.) Dicionário do Brasil Colonial (1500-1808). Rio de Janeiro: Objetiva, 2000. Autor do Verbete: Sheila Siqueira de Castro Faria (SCF) p.126-7.

${ }^{28}$ SLENES, Robert W., op. cit., 1997, p.271.

${ }^{29}$ GÓES, José Roberto, op. cit., 1993, p.102.

${ }^{30}$ Fiz esses cálculos aproximados a partir das listas nominativas de São José dos Pinhais dos anos de 1765, 1781, 1783, 1790, 1793, 1798, 1803, 1810, 1816 e 1818. 